\title{
Inovasi Limbah Cair Singkong Menjadi Nata de Cassava sebagai Bisnis Kuliner
}

Amaliya Sita Permatasari *, Ima Winaningsih, Jamal Adi Prasetiyo

Teknik Kimia, Program Di Luar Domisili (PDD) Politeknik Negeri Bandung, Jl. Bahurekso No 1 Kajen, Kabupaten Pekalongan, Jawa Tengah, Indonesia 51161

\author{
*amalia.sita.pdd@polban.ac.id
}

Submisi: 04 Januari 2019; Penerimaan: 29 November 2019

\begin{abstract}
Tata Kunci:. Abstrak Cellulose bacterial merupakan selulosa yang dibentuk bakteri dengan nata de cassava; pelatihan produksi; rengginang singkong; SCOBY adanya kandungan gula pada limbah. Limbah cair industri berbasis singkong (Manihot esculenta) mengandung gula dengan kadar (5-7)\% sehingga berpotensi sebagai substrat karena telah sesuai dengan kebutuhan minimum glukosa sekitar (67)\% untuk membentuk Cellulose bacterial. Limbah tersebut diperoleh dari limbah cair industri rengginang singkong skala rumah tangga di Desa Nyamok, Kelurahan Kajen, Kabupaten Pekalongan. Namun limbah cair yang dihasilkan menimbulkan bau karena langsung dibuang ke lingkungan. Oleh karena itu, tujuan kegiatan ini sebagai solusi mengatasi pencemaran lingkungan serta meningkatkan pendapatan pengrajin rengginang singkong di Desa Nyamok. Metode yang digunakan yaitu ceramah, demonstrasi, pelatihan produksi, pendampingan dan sosialisasi. Limbah cair hasil pembuatan rengginang singkong dijadikan bahan baku pembuatan nata de cassava dengan bakteri dengan jenis Symbiotic Culture of Bacteria and Yeast (SCOBY) dengan waktu fermentasi 10-14 hari. Kegiatan pelatihan dikategorikan berhasil dengan parameter antara lain rata-rata kehadiran peserta $86 \%$ dengan karakteristik rata-rata berusia diatas 40 tahun dengan sebagian besar memiliki pendidikan terakhir SD. Karakteristik peserta mempengaruhi minat dan kemampuan dalam menyerap informasi baru. Hal tersebut ditunjukkan pada $89 \%$ peserta dapat melakukan pembuatan Nata de cassava dan pemahaman peserta tentang materi penyuluhan diatas target yaitu $80 \%$.
\end{abstract}

Teywords: $\quad$ Abstract Cellulose bacterial is cellulose formed by bacteria sugar content in waste. cassava Cassava-based industrial liquid waste contains sugar (5-7)\%, so it has the potential rengginang; nata de cassava; production training; $S C O B Y$ as a substrate because it meets the minimum glucose requirements of (6-7)\% to form cellulose bacterial. The waste was obtained from liquid waste from home industry cassava rengginang in Nyamok Village. However, liquid waste smells bad because it is directly streamed into the environment. Therefore, the purpose of this activity is to give solutions for overcome environmental pollution and increase the income of cassava rengginang craftsmen in Nyamok Village. The methods are lectures, demonstrations, production training, assistance, and socialization. Liquid waste made from cassava chips was used as raw material for making nata de cassava. It was fermented with Symbiotic Culture of Bacteria and Yeast (SCOBY) bacteria for 10-14 days. Training activities were successful as $86 \%$ people participated in the training. The participants were around 40 years old and elementary school graduates. The characteristics of the participants influence their interest and ability to absorb new information. It is proved by $89 \%$ of the participants are able to make Nata de cassava and their understanding of the counseling material was above the target of $80 \%$. 


\section{PENDAHULUAN}

Singkong (Manihot esculenta) merupakan komoditas hasil pertanian yang mudah rusak karena sifatnya yang sangat peka terhadap infeksi jamur dan mikroba lain. Oleh karena itu, masa simpan singkong dalam bentuk segar setelah panen sangat pendek (Koswara, 2013). Singkong dapat diawetkan dengan diolah menjadi rengginang. Pembuatan rengginang di beberapa daerah sudah dijadikan sebagai bisnis rumahan atau Usaha Kecil dan Menengah (UKM) diantaranya di Jawa Tengah, DI Yogyakarta, Jawa Timur, Jawa Barat dan daerah-daerah lain di luar Jawa.

Desa Nyamok, Kelurahan Kajen, Kabupaten Pekalongan merupakan salah satu daerah di Jawa Tengah yang memiliki kegiatan masyarakat pembuatan rengginang singkong secara berkelompok dan individu. Jumlah kepala keluarga di Desa Nyamok yang memiliki usaha rengginang singkong sekitar 40 keluarga, sehingga makanan ini merupakan potensi khas Desa Nyamok. Umumnya masyarakat di desa ini menggantungkan hidup dari hasil usaha rengginang singkong. Situasi tersebut tidak didukung dengan harga singkong yang terus naik dikarenakan lahan pertanian yang semakin sempit membuat pengusaha rengginang mengalami kendala terhadap bahan baku. Kondisi tersebut diperparah dengan hasil penjualan rengginang masih belum mampu menutupi kebutuhan masyarakat Desa Nyamok, Kecamatan Kajen, Kabupaten Pekalongan. Oleh karena itu, usaha tersebut mengalami penurunan produksi akibat mahalnya harga singkong sehingga untung yang diperoleh sangat minim sehingga usaha ini hanya sebagai sampingan saja.

Rendahnya keuntungan yang diperoleh membuat warga tidak memproduksi rengginang secara berkelanjutan. Oleh karena itu, kegiatan pengabdian masyarakat ini bertujuan untuk meningkatkan kesejahteraan mitra dengan memanfaatkan limbah cair rengginang singkong menjadi nata de cassava. Kegiatan pengabdian tentang pelatihan pembuatan nata de coco yang telah dilakukan antara lain Yudasmara, et al (2015) di 
Buleleng Bali, Nurhasanah, et al. (2017) di Lampung, dan Nurdansyah (2017) di Kabupaten Kudus. Kegiatan pengabdian pada masyarakat ini dilaksanakan bagi kelompok usaha kecil rengginang singkong "Makmur Abadi" yang berlokasi di Desa Nyamok, Kecamatan Kajen, Kabupaten Pekalongan. Sampai saat ini kelompok tersebut memiliki anggota 25 orang, namun ada pula warga yang produksi secara mandiri.

Pada proses pembuatan rengginang singkong, limbah cair dihasilkan dari pencucian, pengepresan, dan pengendapan. Limbah cair tersebut jika dibuang ke lingkungan masih mengandung pati dan akan terurai secara alami sehingga menimbulkan bau yang tidak sedap akibat proses penguraian senyawa yang mengandung nitrogen, sulfur, dan fosfor dari bahan berprotein. Umumnya tiap individu pengrajin rengginang singkong bisa menghasilkan limbah perasan singkong sekitar $20 \mathrm{~L}$ dalam satu kali produksi. Tidak adanya pengolahan limbah di Desa Nyamok menyebabkan Beberapa warga membuang limbah ke selokan sehingga bau tak sedap sering tercium di sekitar rumah warga penghasil rengginang. Umumnya limbah cair proses pembuatan rengginang dialirkan ke dalam galian penampung limbah dan tanpa diolah sebelumnya.

Salah satu solusi untuk mengatasi pencemaran dan meningkatkan nilai tambah bahan buangan dari limbah cair tersebut adalah dengan dimanfaatkan sebagai nata de cassava guna meningkatkan penghasilan warga di Desa Nyamok. Kandungan dalam limbah berupa gula merupakan komponen utama pembuatan Cellulose bacterial oleh symbiotic culture of bacteria and yeast (SCOBY). Pada dasarnya setiap media fermentasi yang mengandung gula dapat digunakan untuk membuat Cellulose bacterial dengan kebutuhan glukosa sekitar (6-7)\%. Kandungan karbohidrat pada limbah tersebut dapat diolah melalui proses hidrolisis dan menghasilkan gula berkadar (5-7)\% (Puspawiningtiyas, 2013). Symbiotic culture of bacteria and yeast (SCOBY) merupakan mikroorganisme gabungan antara bakteri dan khamir sehingga membuat daya tahan 
terhadap kontaminan lebih kuat. Jenis mikroorganisme tersebut lebih menguntungkan karena risiko kegagalan proses pembuatan nata de cassava menjadi lebih kecil. Namun, memerlukan waktu lebih lama untuk membentuk tebal nata $0,8^{-1} \mathrm{~cm}$, yaitu sekitar 2 minggu.

Nata de cassava adalah produk nata berbahan baku singkong atau ubi kayu. Nata de cassava memiliki karakteristik tidak jauh berbeda dengan nata de coco yaitu warna putih, kenyal, dan kandungan seratnya tinggi, hingga 1,7 \% (Salim, 2012). Pemanfaatan limbah menjadi bahan makanan diharapkan menjadi peluang bisnis untuk meningkatkan taraf hidup warga Desa Nyamok yang banyak menggantungkan hidup dari usaha rengginang singkong. Berdasarkan analisa situasi tersebut, maka perlu diadakannya penyuluhan untuk memberikan ketrampilan dalam pengolahan limbah cair rengginang singkong menjadi nata de cassava.

Hipotesa pada kegiatan ini adalah memberikan wawasan tentang pemanfaatan limbah cair rengginang singkong sebagai bahan baku pembuatan nata de cassava, memberikan ketrampilan kepada mitra tentang pembuatan nata de cassava sebagai usaha pemanfaatan limbah cair rengginang singkong, dan memberikan ketrampilan kepada mitra tentang pembuatan minuman dari nata de cassava. Oleh karena itu, tujuan kegiatan ini ada dua, yakni sebagai solusi mengatasi pencemaran lingkungan akibat limbah rengginang singkong dan meningkatkan pendapatan pengrajin rengginang singkong di Desa Nyamok, Kecamatan Kajen, Kabupaten Pekalongan, Provinsi Jawa Tengah.

\section{MASALAH}

Berdasarkan latar belakang mitra di Desa Nyamok Kecamatan Kajen, maka dapat dikemukakan rumusan masalah sebagai berikut : 
a. Upaya seperti apa dalam memberikan wawasan kepada mitra tentang pemanfaatan limbah cair rengginang singkong sebagai bahan baku pembuatan nata de cassava dengan penambahan gula dan teh?

b. Upaya seperti apa dalam memberikan ketrampilan kepada mitra tentang pembuatan nata de cassava sebagai usaha pemanfaatan limbah cair rengginang singkong?

c. Upaya seperti apa dalam memberikan ketrampilan kepada mitra tentang pembuatan minuman dari nata de cassava sebagai bisnis kuliner?

\section{METODE}

\subsection{Metode Pembuatan Nata de Cassava}

Proses pembuatan nata de cassava terdiri dari penyaringan, perebusan, penuangan, inokulasi, pemeraman/fermentasi, pemanenan, dan pengolahan. Produk setengah jadi ini berupa lembaran atau potongan nata de cassava. Prosedur pembuatan Nata de cassava terdiri dari beberapa tahapan. Tahap pertama yaitu penyaringan dengan menyaring limbah rengginang menggunakan saringan yang dilapisi kain atau nilon. Tahap kedua adalah perebusan dengan mendidihkan substrat dan memasukkan gula hingga larut dengan resep 50g/L. Menambahkan kantong teh dengan ukuran 1-2 kantong tiap liter limbah.

Tahap selanjutnya adalah pendinginan dengan mendinginkan limbah hingga suhu ruang. Lalu, menyaring kembali dengan kain untuk mengurangi endapan pati yang masih tersisa. Tahap selanjutnya adalah mempersiapkan bahan fermentasi dengan memotong lapisan nata (starter sebelumnya) dan menyetrika kain/koran. Tahap terakhiradalah pemeraman dengan menuang limbah dalam nampan dan memasukkan potongan nata ke dalam nampan atau toples. Kemudian, ditutup menggunakan koran atau kain dan ikat dengan karet. Lalu, didiamkan selama 14 hari untuk mendapatkan lapisan nata yang tebal. 
Setelah proses fermentasi berlangsung sekitar 10-14 hari maka dapat dilakukan pemanenan. Nata hasil panen memiliki ketebalan rata-rata $0,8-1 \mathrm{~cm}$. Nata lembaran yang memiliki kualitas baik dengan yang kualitasnya kurang baik, dilihat dari ketebalan dan bentuknya. Kiteria nata yang baik selain memiliki ketebalan rata-rata juga dianalisa dari banyak sedikitnya kontaminan jamur pada lembaran nata. Jika lebih dari $25 \%$ maka nata tersebut termasuk produk gagal. Standar mutu nata menurut SNI 01-4317 1996 ada beberapa parameter, namun yang digunakan sebagai standar dalam pemanenan hanya parameter keadaan (bau, rasa, warna, tekstur). Nata yang berkualitas prima memiliki bau asam, warna putih susu atau putih kekuningan dan tekstur kenyal tanpa jamur.

Selain itu, penyuluhan analisis usaha Nata de cassava ini bertujuan untuk memberikan pengetahuan dalam bentuk analisa usaha agar mitra mengetahui peluang usaha yang telah ditawarkan. Analisa ini dilakukan dengan menghitung analisa kebutuhan modal, analisa biaya produksi dan untung-rugi tiap bulannya.

\subsection{Teknik Pengumpulan Data}

Penelitian ini menggunakan beberapa metode dalam pengumpulan data. Metode yang digunakan anatar lain dengan ceramah, demonstrasi, penyuluhan produksi, dan pendampingan. Metode ceramah bertujuan untuk mensosialisasikan pemanfaatan limbah cair sebagai nata de cassava guna meningkatkan nilai ekonomis dan dilakukan dengan dialog interaktif. Metode selanjutnya adalah demonstrasi. Metode ini bertujuan untuk mempraktikan dengan cara simulasi tentang proses peremajaan starter SCOBY, prosedur pembuatan nata de cassava serta kondisi khusus yang harus diperhatikan dalam pembuatan nata de cassava dan pembuatan minuman olahanya.

Metode selanjutnya adalah penyuluhan produksi. Metode ini merupakan tahap penting dari kegiatan pengabdian masyarakat yang bertujuan untuk memberikan keterampilan dalam pemanfaatan limbah cair rengginang sebagai nata de cassava. 
Peserta yang terdiri dari mitra dan masyarakat sekitar akan mempraktikkan cara pembuatan nata de casaava. Metode terakhir adalah Pendampingan. Pendampingan merupakan tindak lanjut dari kegiatan penyuluhan yang dilakukan dengan memantau dan memberikan bantuan langsung kepada ibu rumah tangga yang bersedia mempraktikkan pembuatan nata de cassava di tempat tinggal masing-masing peserta. Kegiatan ini dilakukan dengan mendatangi langsung rumah-rumah warga secara terpisah pada tanggal 11 November 2018 dan melalui kegiatan PKK pada tanggal 15 November 2018.

\subsection{Teknik Analisa Data, Lokasi dan Durasi Kegiatan}

Evaluasi hasil pelaksanaan kegiatan penyuluhan dilakukan terhadap proses dan produk kegiatan. Evaluasi proses dianalisa pada kehadiran peserta, antusiasme mitra mengikuti kegiatan, dan tanggapan/respon masyarakat terhadap pelaksanaan kegiatan. Kehadiran peserta diukur dengan absensi kegiatan, kemudian dinyatakan dalam bentuk persentase kehadiran peserta. Evaluasi produk dilakukan dalam bentuk angket dan dinyatakan dalam bentuk diagram batang.

Kegiatan dilakukan di dua lokasi, yaitu Desa Nyamok dan Kampus PDD Politeknik Negeri Bandung. Waktu Pelaksanaan dimulai dari Bulan Juli-November 2018. Durasi Kegiatan dilakukan dua hari sabtu dan minggu 20-21 Oktober 2018.

\section{HASIL DAN PEMBAHASAN}

\subsection{Studi Lapangan ke Mitra}

Kegiatan ini diawali dengan studi lapangan pada mitra penghasil rengginang singkong dan pembuatan nata de cassava (Gambar 1). Tujuan kegiatan tersebut untuk mengetahui proses pembuatan rengginang, melakukan wawancara tentang bisnis rengginang, serta menjalin kerja sama untuk penyediaan limbah cair sebagai bahan baku 
(Gambar 2). Karakteristik limbah yang digunakan adalah limbah yang masih segar dan mengandung gula sekitar (6-7)\% (Puspawiningtiyas, 2013). Limbah cair tersebut dibuang ke sungai tanpa proses pengolahan terlebih dahulu.

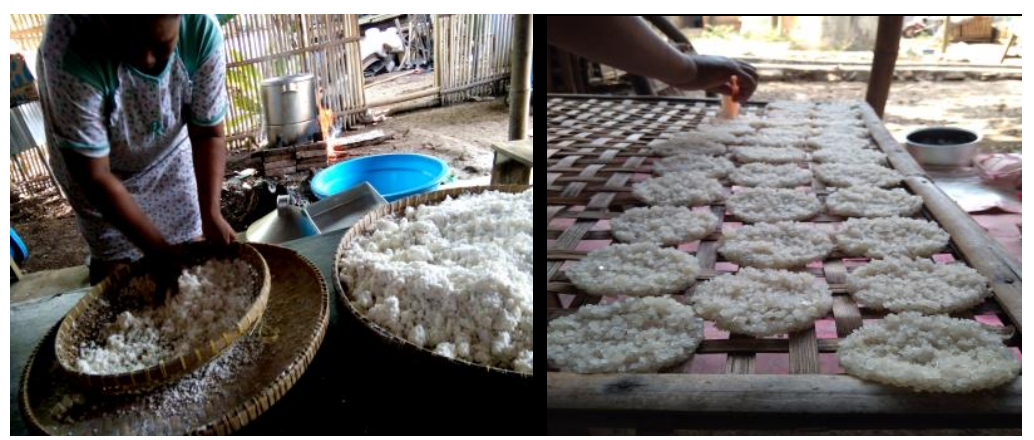

Sumber: Data primer diolah (2018)

Gambar 1. Proses Pembuatan Rengginang (Kiri) dan Rengginang Singkong (Kanan)

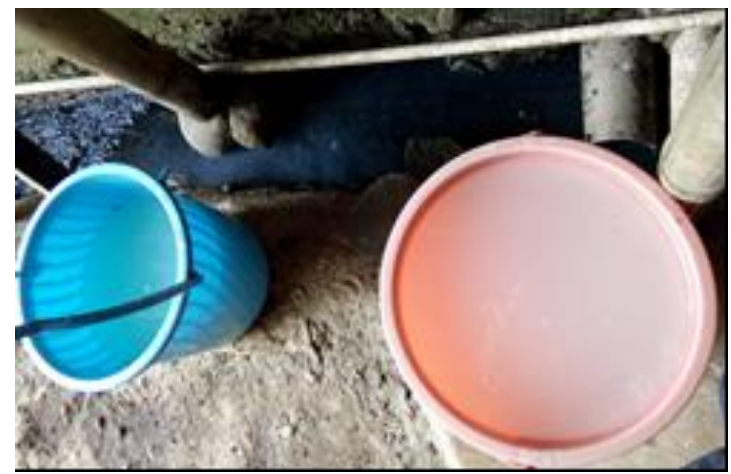

Sumber: Data primer diolah (2018)

Gambar 2. Limbah Cair dari Rengginang

Berdasarkan hasil studi lapangan tersebut diperoleh data untuk setiap kali produksi, mitra menggunakan $250 \mathrm{~kg}$ (1/4 kuintal) ketela pohon dengan harga Rp50.000,00 dengan penghasilan kotor total Rp108.000,00 dan bahan lain yang digunakan, antara lain bawang putih, garam, dan penyedap. Proses pembuatan rengginang singkong memerlukan waktu sekitar 2-3 hari dari proses persiapan bahan hingga pengemasan dan sangat dipengaruhi cuaca, sedangkan harga jual 1 kemasan isi 20 biji sebesar Rp3000,00. Warga bisa menghasilkan 36 bungkus dari 1/4 kuintal singkong. Penghasilan kotor pelaku usaha rengginang sekitar Rp3.000,00 x $36=$ Rp108.000,00. Pada musim kemarau, mitra mengalami kesulitan untuk memperoleh bahan baku singkong yang berkualitas. Proses pembuatan rengginang dimulai dari 
persiapan bahan baku dan alat (pemarutan singkong, penyiapan bumbu dan peralatan produksi), perendaman dan pemisahan pati, pencampuran ampas dengan bumbu, pengukusan, pencetakan, penjemuran, dan packaging.

\subsection{Pembuatan Nata de Cassava}

Limbah cair hasil pembuatan rengginang singkong dijadikan bahan baku pembuatan nata de cassava dengan bakteri dengan jenis symbiotic culture of bacteria and yeast (SCOBY). Indukan bakteri nata tersebut biasanya disebut dengan starter bakteri. Pemilihan mikroorganisme tersebut berdasarkan Crum (2016). SCOBY umumnya digunakan sebagai mikroorganisme untuk memproduksi kombucha dengan media air teh dengan ketahanan untuk berkembang lebih baik dan lebih mudah dikembangbiakkan daripada bakteri Acetobacter xylinum yang umum digunakan untuk nata de coco.

Limbah rengginang yang telah disaring ditambahkan teh 1-2 kantong/L (jenis teh original) dan gula $50 \mathrm{~g} / \mathrm{L}$. Kemudian, setelah dingin ditambahkan starter sekitar $10 \%$ dari volume kemudian ditutup dengan koran dan difermentasi selama 10-14 hari hingga terbentuk lapisan nata de cassava (Gambar 3).

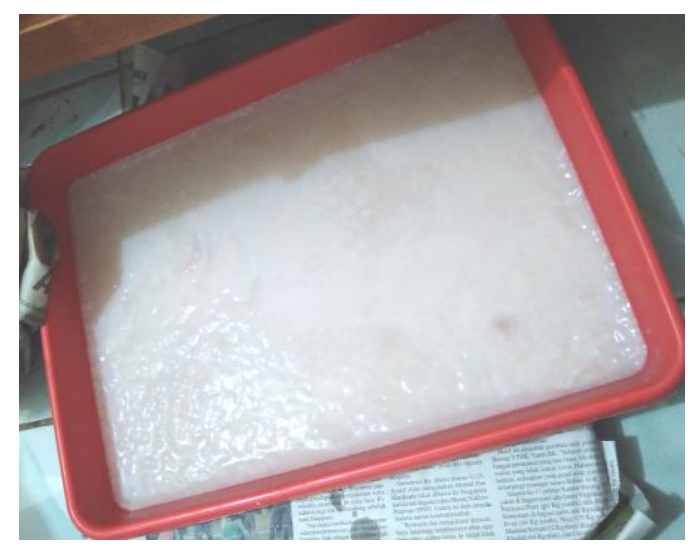

Sumber: Data primer diolah (2018)

Gambar 3. Hasil Nata de Cassava Optimal Pada Nampan Ukuran 27 x $5 \mathrm{~cm}^{3}$

Lembaran nata de cassava yang telah jadi direndam selama semalam, kemudian dipotong dadu dan direbus dua kali untuk menghilangkan rasa masam (Salim, 2012). 
Nata yang telah direbus diolah menjadi minuman dan dikemas dengan wadah plastik.

Pengemasan minuman dilakukan proses sterilisasi terlebih dahulu dengan merebus kedalam air panas suhu $80^{\circ} \mathrm{C}$ selama 2 menit dan didinginkan dalam suhu ruang. Tujuan proses ini untuk meminimalkan kontaminasi dari bakteri yang bisa merusak rasa dan kondisi bahan makanan.

\subsection{Kegiatan Penyuluhan}

Kegiatan penyuluhan di Dukuh Tambor, Desa Nyamok, Kec. Kajen dilakukan oleh dosen, teknisi laboratorium, dan mahasiswa Teknik Kimia PDD POLBAN dengan peserta sebanyak 22 peserta. Acara pembukaan diwakili oleh Bapak Daryanto, S.I.P. selaku Kepala Desa Nyamok dan Bapak Drs. Mujiyanto selaku koordinator pengelola PDD Politeknik Negeri Bandung.

Umumnya peserta merupakan ibu rumah tangga dengan kisaran umur 30-60 tahun dan sebagian besar berlatar belakang pendidikan SD. Mitra pada kegiatan ini merupakan pelaku usaha rengginang singkong skala rumah tangga. Karakteristik tersebut yang menyebabkan kendala pada minat peserta untuk mengembangkan usaha nata de cassava yang cukup rendah.

Analisa kemampuan awal mitra dilakukan dengan pemberian pre-test di awal kegiatan. Tujuan pemberian tes ini yaitu untuk mengetahui informasi yang telah dimiliki mitra tentang nata de cassava dan pengalaman mengikuti pelatihan sejenis sebelumnya. Hasil tes menunjukkan hampir seluruh mitra belum memiliki pengetahuan dan pengalaman tentang nata de cassava (Gambar 4). 


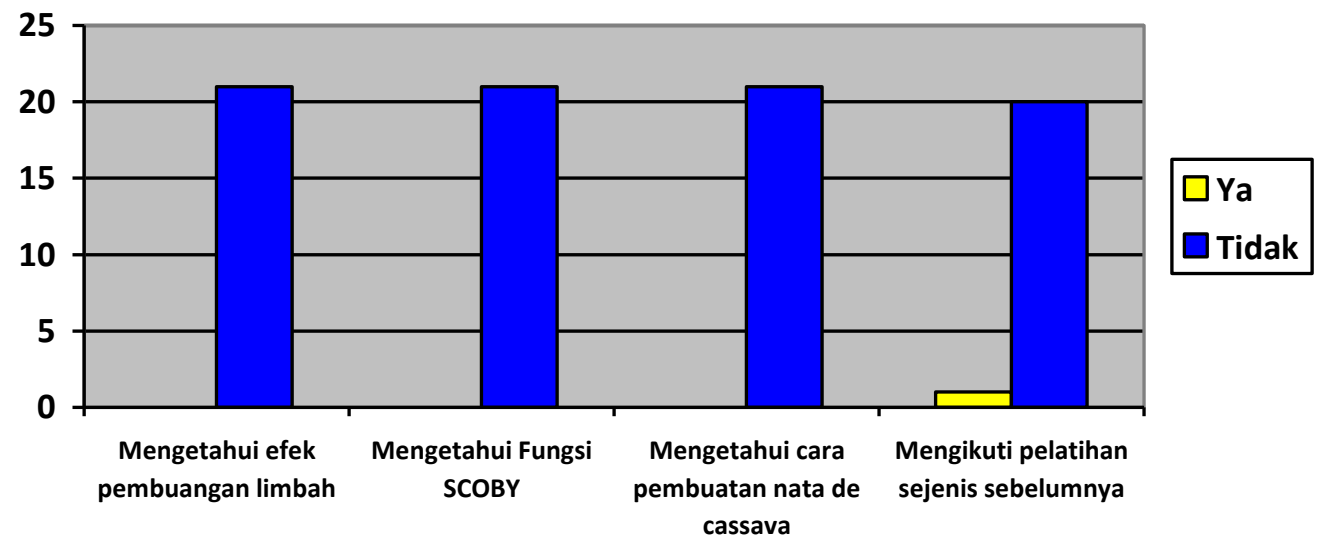

Sumber: Data primer diolah (2018)

Gambar 4. Grafik Hasil Pre Test Evaluasi pada Produsen Nata de Cassava

Metode pelaksanaan kegiatan adalah penyuluhan/penyadaran dan pelatihan produksi. Penyuluhan dilakukan dengan teknik ceramah dan dilanjutkan dengan demonstrasi serta pelatihan produksi. Sesi tanya jawab dilakukan secara berurutan dan diikuti dengan kegiatan pelatihan produksi yang terbagi menjadi empat kelompok. Masing-masing kelompok didampingi oleh mahasiswa.

Setelah kegiatan penyuluhan dan pelatihan produksi selesai, dilakukan post-test untuk mengukur keberhasilan kegiatan dari pemahaman peserta. Hasil post-test menunjukkan peserta telah memahami proses pembuatan nata de cassava sebagai solusi pemanfaatan limbah. Beberapa peserta ada yang merasa masih belum tahu atau tidak lancar sebanyak 1-2 orang, dan rata-rata yang merasa kurang terampil sebanyak tujuh orang. Karakteristik peserta berupa usia, dan latar belakang pendidikan dapat mempengaruhi kecepatan peserta dalam menerima materi. Peserta yang kurang memiliki perubahan signifikan memiliki usia 58 dan 60 tahun. Berdasarkan hasil tersebut, $80 \%$ peserta dapat memahami materi yang disampaikan dan $89 \%$ peserta dapat melakukan praktek pembuatan nata de cassava. Dalam kategori produksi makanan olahanya, dapat disimpulkan bahwa peserta telah lancar atau kurang lancar. 


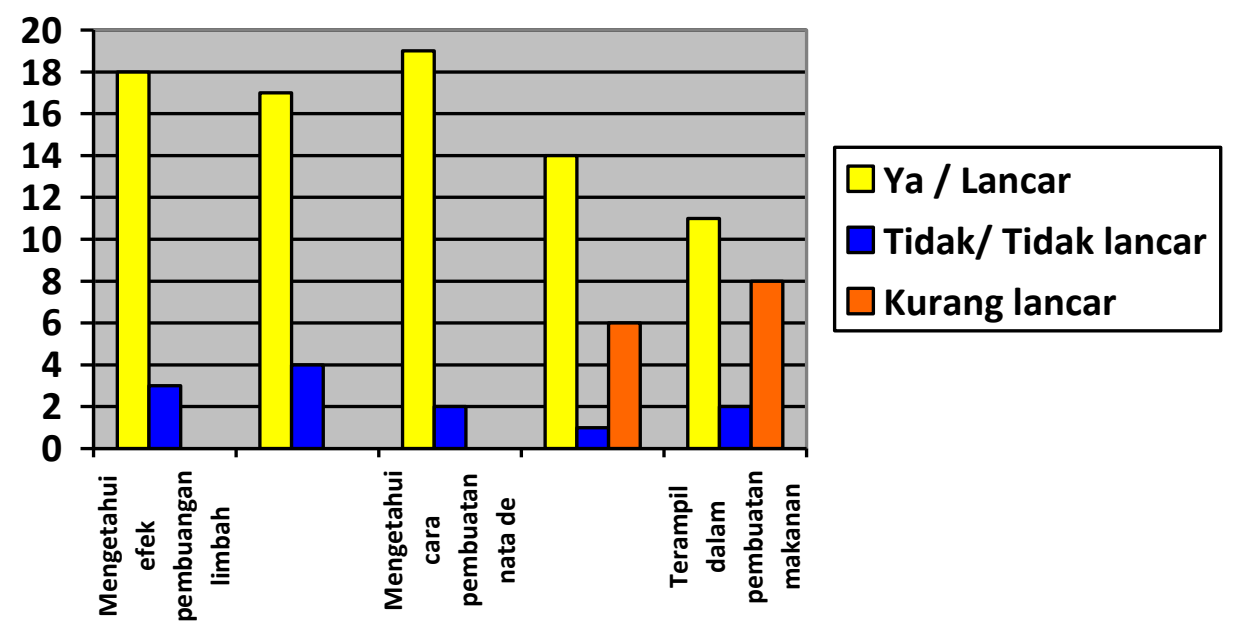

Sumber: Data primer diolah (2018)

Gambar 5. Grafik Hasil Post Test Evaluasi Produsen Nata de Cassava

Angket post test berupa pertanyaan dengan kategori jawaban ya/tidak, lancar/kurang lancar/ tidak lancer (Gambar 5). Kategori jawaban ya/tidak meliputi pertanyaan sebagai berikut:

1. Apakah anda sudah mengetahui bahaya pembuangan air limbah rengginang singkong tanpa pengolahan ke lingkungan?

2. Apakah Anda mengetahui fungsi bakteri SCOBY dalam pembuatan nata?

3. Apakah Anda sudah mengetahui cara untuk memanfaatkan air limbah rengginang singkong menjadi nata de cassava?

4. Apakah bimbingan yang diberikan instruktur dalam pelatihan mudah dimengerti?

5. Apakah isi dan metode pelatihan ini memuaskan?

6. Apakah Anda tertarik untuk berwirausaha membuat olahan pangan dari nata de cassava?

Kategori lancar/kurang lancar/ tidak lancar meliputi pertanyaan :

1. Apakah Anda dapat dengan lancar membuat nata de cassava dari air limbah rengginang singkong?

2. Apakah Anda dapat dengan lancar membuat olahan pangan dari nata de cassava? 
Tanggapan atau respon peserta terhadap kegiatan pengabdian berkaitan dengan kemudahan pemateri dalam menyampaikan, kepuasan isi pelatihan dan penilaian diri peserta terhadap penguasaan materi setelah pelatihan. Semangat atau antusiasme dinilai dari komentar yang diberikan peserta setelah pelatihan. Tanggapan peserta pelatihan disajikan pada Tabel 1 dan Tabel 2 menunjukkan antusiasme untuk mengikuti pelatihan sejenis atau pengembangan usaha yang sudah disampaikan.

Tabel 1. Tanggapan Peserta Terhadap Kegiatan Pelatihan

\begin{tabular}{|c|c|c|c|c|c|c|c|c|c|}
\hline \multirow{2}{*}{ No } & \multirow{2}{*}{ Indikator } & \multicolumn{2}{|c|}{ Jawaban } & \multicolumn{5}{|c|}{ Persentase Penguasaan (\%) } & \multirow{2}{*}{$\begin{array}{l}\text { Rata-Rata } \\
(\%)\end{array}$} \\
\hline & & Ya & Tidak & $<50$ & 60-69 & 70-80 & 81-90 & 100 & \\
\hline 1 & $\begin{array}{l}\text { Kemudahan } \\
\text { Penyampaian } \\
\text { Pemateri }\end{array}$ & 20 & 1 & & & & & & 95 \\
\hline 2 & $\begin{array}{l}\text { Kepuasan Isi } \\
\text { Pelatihan }\end{array}$ & 21 & 0 & & & & & & 100 \\
\hline 3 & $\begin{array}{l}\text { Penguasaan Materi } \\
\text { Setelah Pelatihan }\end{array}$ & - & - & 5 & 1 & 9 & 4 & 2 & 74.4 \\
\hline
\end{tabular}

Sumber: Data primer diolah (2018)

Tabel 2. Antusiasme Peserta dalam Mengikuti Kegiatan Pelatihan

\begin{tabular}{lll}
\hline No & \multicolumn{1}{c}{ Komentar peserta } & Jumlah \\
\hline 1 & Mengadakan pelatihan secara berkelanjutan (1 bulan sekali) & 11 \\
2 & Meminta kesediaan mengisi acara di Desa Nyamok & 1 \\
3 & Pendampingan penjualan nata de cassava & 4 \\
4 & Tidak ada komentar & 5 \\
\hline
\end{tabular}

Sumber: Data primer diolah (2018)

Berdasarkan tabel tersebut terlihat kepuasan dan antusiasme peserta pada pelatihan ini baik. Beberapa peserta memiliki tanggapan yang kurang sesuai dengan tujuan kegiatan disebabkan oleh usia sehingga menurunkan minat dan mempengaruhi keseriusan dalam mengikuti pelatihan maupun timbulnya keengganan dalam mengisi angket. 


\subsection{Analisa Hasil Evaluasi Kegiatan}

Deskripsi evaluasi kegiatan pelatihan dianalisa berdasarkan beberapa kriteria antara lain target peserta penyuluhan yang ditetapkan sebelumnya sejumlah 20 orang, jumlah peserta yang hadir 22 dan 21 orang meskipun peserta yang diundang sejumlah 25 orang. Rata-rata kehadiran peserta sejumlah $86 \%$ dengan karakteristik peserta rata-rata berusia diatas 40 tahun dengan sebagian besar memiliki pendidikan terakhir SD.

Kriteria kedua berdasarkan evaluasi kegiatan hasil post test diperoleh persentase 89\% peserta dapat memahami dan lancar atau kurang lancar untuk melakukan pelatihan pembuatan Nata de cassava. Variabel yang ditekankan yaitu terampil dalam membuat Nata de cassava dan makanan olahanya.

Kriteria ketiga berdasarkan evaluasi kegiatan hasil post test diperoleh data $80 \%$ peserta telah memahami materi yang disampaikan yaitu tentang fungsi SCOBY dan cara pembuatan Nata de cassava. Prosentase tersebut sudah diatas target sehingga dapat dijadikan kriteria keberhasilan. Materi yang dipahami terdiri atas: (1) peranan bakteri SCOBY pada proses pembuatan Nata de cassava; (2) proses dan kondisi khusus dalam pembuatan Nata de cassava; dan (3) terampil dalam pembuatan Nata de cassava dari limbah cair rengginang singkong.

Kriteria keempat yaitu prosentase pemahaman peserta sudah diatas target yaitu $80 \%$ Variabel yang ditekankan berupa pengetahuan tentang efek pembuangan limbah yang terdiri dari: (1) pembuatan minuman Nata de cassava dengan bahan baku limbah cair rengginang singkong dan (2) meningkatkan kesadaran untuk berwirausaha mengolah limbah cair menjadi Nata de cassava.

\subsection{Analisa Usaha Nata de Cassava}

Analisa usaha nata de cassava dari segi keuntungan bertujuan agar mitra mengetahui potensi pendapatan dengan memproduksi nata de cassava dalam bentuk lembaran. 
Asumsi yang digunakan dalam menganalisis segi ekonomi untuk usaha lembaran nata de cassava adalah bahan baku berupa limbah dari hasil produksi pembuatan rengginang yang diperoleh secara cuma-cuma. Analisa ekonomi harga limbah terhitung $\mathrm{Rp} 0,00$ karena memanfaatkan limbah produksi sebelumnya.

Analisa usaha dilakukan dengan menghitung kebutuhan modal, dan biaya produksi tiap bulan. Kebutuhan modal diperoleh dari penjumlahan dari modal tetap dengan modal kerja. Pada Lampiran (Tabel 1), modal tetap yang diperlukan sebesar Rp. 1.847.000 dan modal kerja tetap sebesar Rp 1.220.650 yang ditunjukkan pada Lampiran (Tabel 2). Total kebutuhan modal yang diperlukan sebesar Rp. 3.067.650. Perhitungan biaya produksi tiap bulan diperoleh dari biaya tetap dan biaya tidak tetap. Variabel biaya tetap antara lain gaji karyawan, penyusutan alat dan biaya modal. Berdasarkan Lampiran (Tabel 3), total biaya tetap pada usaha ini sebesar Rp. 1.023.612. Biaya tidak tetap pada Lampiran (Tabel 4) terhitung sebesar Rp. 166.500.

Berdasarkan perhitungan tersebut, dapat didapatkan biaya produksi tiap bulan dengan mengakumulasikan biaya tetap dan biaya tidak tetap sebesar Rp1.190.112. Harga jual nata dalam bentuk lembaran dipatok sekitar Rp10.000,00/lembar. Asumsi yang dilakukan jika satu kali produksi menggunakan limbah rengginang sebanyak 50 liter maka akan menghasilkan \pm 40 lembar nata de cassava. Untuk ketersediaan limbah diasumsikan tersedia minimal 4 hari dalam seminggu, maka dalam satu bulan proses produksi dilakukan 4 x $4=16$ hari.

Perancangan usaha ini, jika dihitung keuntungan dan kerugian tiap bulan berdasarkan hasil penjualan dan biaya produksi diperoleh penghasilan tiap bulan sebesar Rp. 409.888 yang ditunjukkan pada Lampiran (Tabel 5). Berdasarkan analisa usaha tersebut, mitra dapat memiliki pendapatan tambahan dengan memanfaatkan limbah cair rengginang singkong menjadi lembaran nata de cassava sebesar Rp409.888,00 tiap 
bulanya. Nata de cassava berbentuk lembaran dapat dimanfaatkan oleh industri nata atau diolah menjadi mminuman dengan harga jual lebih tinggi.

\subsection{Kegiatan Pendampingan dan Sosialisasi}

Tindak lanjut dari kegiatan pengabdian masyarakat di Desa Nyamok adalah diadakannya pendampingan dan sosialisasi. Tujuan kegiatan pendampingan antara lain untuk memfasilitasi mitra dan mempermudah dalam praktek secara mandiri di rumah masing-masing. Tim mendatangi mitra dan memberikan bantuan usaha berupa gula, teh, nampan, koran, dan karet. Mitra hanya membutuhkan kompor dan panci serta mendapatkan bantuan dan bimbingan langsung dari tim. Sistem ini merupakan home visit yang terdiri dari pembuatan starter bakteri dan praktek pembuatan nata.

Kegiatan sosialisasi bertujuan untuk memperluas jumlah sasaran kegiatan pengabdian masyarakat, tidak hanya bagi pelaku usaha rengginang singkong namun juga ibu rumah tangga yang memiliki minat dan ketertarikan untuk memproduksi nata de cassava. Sosialisasi tersebut telah dilaksanakan dengan memberikan penyuluhan pada kegiatan PKK di Desa Nyamok pada tanggal 15 November 2018 di Aula Balai Desa Nyamok. Kegiatan tersebut dapat terselenggara atas permintaan ibu Kepala Desa Nyamok, sehingga cakupan penyuluhan tidak hanya ditujukan pada lingkup pelaku usaha tapi nantinya dapat dilakukan pada kegiatan RT atau RW.

Kendala dari kegiatan pengabdian masyarakat antara lain terbatasnya informasi secara akurat dari desa terkait jumlah konkret UKM rengginang singkong dan rendahnya kesadaran untuk mengatasi permasalahan lingkungan akibat limbah. Faktor penting yang lain adalah peserta yang didominasi ibu rumah tangga dengan pendidikan SD mempengaruhi minat dan kemampuan dalam menyerap informasi baru. Kegiatan dikategorikan berhasil dengan parameter jumlah peserta melebihi target dan hasil posttest menunjukkan adanya peningkatan terhadap pemahaman materi tentang pembuatan 
Nata de Cassava dan makanan olahanya dengan persentase $80 \%$, semangat/antusiasme serta tanggapan/respon peserta mengikuti kegiatan dengan kategori baik yang diperoleh dari hasil angket.

\section{KESIMPULAN}

Berdasarkan uraian pada hasil dan pembahasan kegiatan penyuluhan dapat disimpulkan bahwa kegiatan dikategorikan berhasil dengan parameter jumlah peserta melebihi target dan hasil post test menunjukkan adanya peningkatan terhadap pemahaman materi tentang pembuatan Nata de Cassava. Karakteristik peserta mempengaruhi minat dan kemampuan dalam menyerap informasi baru. Hal tersebut ditunjukkan pada hasil tes yang kurang pada peserta dengan umur diatas 58 tahun dan berlatar belakang pendidikan SD. Kegiatan pendampingan dilakukan untuk menindaklanjuti pasca kegiatan sehingga mitra dapat mempraktikkan secara mandiri. Jumlah warga yang mengikuti kegiatan ini secara mandiri sebanyak 3 orang, sedangkan sisanya mengikuti dalam rangka kegiatan PKK.

Program Pengabdian Masyarakat di Desa Nyamok perlu disempurnakan dengan beberapa saran antara lain perlu dilakukan kerjasama dengan dinas terkait untuk mengadakan kegiatan ini secara rutin dan bertahap di desa-desa yang berpotensi sebagai sentra usaha berbasis singkong. Diperlukan kerjasama dengan pihak terkait mengenai ijin edar produk minuman, food safety management system, dan pengetahuan packaging.

\section{DAFTAR PUSTAKA}

Crum, H., \& La Gory, A. (2016). The Big Book of Kombucha, Brewing, Flavoring and Enjoying the Health Benefits of Fermented Tea. North Adams: Storey Publishing. 
Koswara, S. (2013). Modul Teknologi Pengolahan Umbi-Umbian Bagian 6: Pengolahan Singkong. Tropical Plant Curriculum (TPC) Project. Bogor Agricultural University: Southeast Asian Food and Agricultural Science and Technology.

Nurhasanah, Laila, A., Mulyono, Rilyanti, M., dan Noviany. (2017). Pelatihan Pembuatan Nata De Coco Secara Higienis Bagi Masyarakat Desa Fajar Baru Lampung Selatan. Universitas Lampung.

Salim, E. (2012). Dari Limbah Menjadi Rupiah Nata De Coco, Nata De Soya Nata De Cassava. Yogyakarta: Lily publisher.

Salim, E. (2012). Sukses Bisnis Nata De Cassava Skala Rumah Tangga. Yogyakarta: Lily publisher.

Puspawiningtiyas, E., \& Ma'ruf A. (2013). Kajian Awal Pemanfaatan Limbah Tepung Tapioka Sebagai Substrat Pembuatan Nata. Jurnal Fakultas Teknik Universitas Muhammadiyah Purwokerto, 14(2): 42-51.

Yudasmara, Gede A., Sukarta, I N., dan Wisnawa, I Gede Y. (2015). Pelatihan Pembuatan Nata De Coco Dan Minyak Kelapa Hemat Energi Bagi Kelompok Wanita Tani Di Desa Tukad Mungga Kecamatan Buleleng. Universitas Pendidikan Ganesha. 


\section{Lampiran 1. Perhitungan}

Tabel 1. Analisa Kebutuhan Modal Tetap

\begin{tabular}{llll}
\hline No & \multicolumn{1}{c}{ Jenis investasi } & Unit & \multicolumn{1}{c}{$\begin{array}{c}\text { Harga total } \\
\text { (Rp) }\end{array}$} \\
\hline 1. & Biaya pengiriman/pengambilan starter & 1 & 15.000 \\
2. & Alat sealer gelas & 1 & 180.000 \\
3. & Peralatan produksi: & & \\
& - Nampan plastik (@96.000) & 4 lusin & 384.000 \\
& - Ember plastik (@30.000) & 4 buah & 120.000 \\
- Kompor (@75.000) & 2 buah & 150.000 \\
- Pisau & 1 buah & 25.000 \\
- Panci kapasitas max 10 Lt (@300.000) & 2 buah & 600.000 \\
- Pengaduk stainless steel & 1 buah & 8.000 \\
- Telenan & 1 buah & 20.000 \\
- Jurigen plastik kapasitas 25 L & 1 buah & 30.000 \\
- Saringan plastik & 1 buah & 10.000 \\
- Toples kaca (kapasitas 2 L) & 1 buah & 120.000 \\
- Gelas ukur plastik 2 L & 1 buah & 20.000 \\
- Timbangan 1000 gram & 1 buah & 30.000 \\
- Tabung gas 12 kg & 1 buah & 135.000 \\
\hline TOTAL & & $\mathbf{1 . 8 4 7 . 0 0 0}$ \\
\hline
\end{tabular}

Sumber: Data Primer Diolah (2018)

Tabel 2. Analisa Kebutuhan Modal Kerja Per Bulan

\begin{tabular}{|c|c|c|c|}
\hline No & Modal Kerja & Unit Perbulan & $\begin{array}{l}\text { Harga total } \\
\text { (Rp) }\end{array}$ \\
\hline 1 & Biaya pembelian starter bakteri (@20.000 kapasitas 1 Lt) & - & 10.000 \\
\hline 2. & Gas LPG & 10 kali isi ulang & 200.000 \\
\hline 3. & Gula pasir (@12.000/kg) & $1 \mathrm{~kg}$ & 12.000 \\
\hline 4. & Teh celup (@4500) & 1 pak & 4.500 \\
\hline 5. & Sarana air & 100 liter & 50.000 \\
\hline 6. & Sarana listrik & - & 100.000 \\
\hline 7. & Koran bekas (@2500/kg) & 2 & 5.000 \\
\hline 8. & Karet & 1 pak & 25.000 \\
\hline 9 & Gaji karyawan (@600.000/26 hari kerja) & 1 orang & 600.000 \\
\hline 10. & Biaya Kemasan (gelas plastik dan sealer) & 1 paket & 50.000 \\
\hline 11. & Transportasi & Dalam kota & 70.000 \\
\hline 12. & Limbah cair perasan singkong & $20 \mathrm{~L}$ & - \\
\hline \multirow[t]{2}{*}{13.} & Biaya tak terduga: $10 \%$ modal & - & 94.150 \\
\hline & TOTAL & & 1.220 .650 \\
\hline
\end{tabular}

Sumber: Data Primer Diolah (2018)

Total Kebutuhan Modal

$=$ modal tetap + modal kerja

$=\mathrm{Rp} 1.847 .000,00+\mathrm{Rp} 1.220 .650,00$

$=\mathrm{Rp} 3.067 .650,00$

(Data Primer Diolah, 2018) 
Tabel 3. Perhitungan Biaya Tetap Produksi Tiap Bulan

\begin{tabular}{lll}
\hline No & Biaya tetap & Jumlah $(\mathbf{R p )}$ \\
\hline 1 & Gaji karyawan & 600.000 \\
2 & Penyusutan alat(10\%) & 178.200 \\
3 & Biaya modal 8\% & 245.412 \\
\hline Total biaya tetap & $\mathbf{1 . 0 2 3 . 6 1 2}$
\end{tabular}

Sumber: Data primer diolah (2018)

Tabel 4. Perhitungan Biaya Tidak Tetap Produksi Tiap Bulan

\begin{tabular}{|c|c|c|c|}
\hline No & Biaya Tidak Tetap & Satuan & $\begin{array}{c}\text { Jumlah } \\
\text { (Rp) }\end{array}$ \\
\hline 1 & Biaya pembelian starter bakteri (@ 20.000 kapasitas $1 \mathrm{Lt}$ ) & & 20.000 \\
\hline 2. & Tabung Gas LPG & 1 & 135.000 \\
\hline 3. & Gula pasir (@11.000/kg) & $1 \mathrm{~kg}$ & 12.000 \\
\hline 4. & Teh celup (@4500) & 1 pak & 4500 \\
\hline 5. & Sarana air & 100 liter & 50.000 \\
\hline 6. & Sarana listrik & & 50.000 \\
\hline 7. & Koran bekas (@2500/kg) & 2 & 5.000 \\
\hline & Karet & 1 pak & 25.000 \\
\hline \multicolumn{3}{|c|}{ Total biaya tidak tetap } & 166.500 \\
\hline
\end{tabular}

Sumber: Data Primer Diolah (2018)

Biaya produksi perbulan

= biaya tetap + biaya tidak tetap

$=\mathrm{Rp} 1.023 .612,00+\mathrm{Rp} 166.500,00$

$=\mathrm{Rp} 1.190 .112,00$

Sumber: Data primer diolah (2018)

Tabel 5. Rugi-Laba Tiap Bulan

\begin{tabular}{llll}
\hline No & Uraian & Perhitungan & Jumlah $(\mathbf{R p )}$ \\
\hline 1. & Hasil penjualan & $10000 \times 40 \times 4$ & 1.600 .000 \\
2. & Biaya produksi & & 1.190 .112 \\
\hline Penghasilan bersih/bulan & & $\mathbf{4 0 9 . 8 8 8}$
\end{tabular}

Sumber: Data primer diolah (2018) 